\title{
Exploration and Practice of College-Enterprise Cooperation Training Applied Talents Model_Case Study of Applied electronic technology Majorof the City Vocational College of Jiangsu
}

\author{
CHEN Wei ${ }^{1, a}$, JIANG Chun-yan ${ }^{2, b}$ \\ ${ }^{1}$ The City Vocational College of Jiangsu , Nanjing, 210036,China \\ ${ }^{2}$ The City Vocational College of Jiangsu , Nanjing, 210036,China \\ aemail: chenwei@jstvu.edu.cn, ${ }^{\mathrm{b}}$ email: jiangchunyan@jstvu.edu.cn
}

Key words College-enterprise cooperation; post-oriented; integrating theory with practice

\begin{abstract}
Training applied talents model on colle ge-enterprise cooperation - "post-oriented, integrating theory with practice" had put forward. In the following several aspects to cooperatin g: formulating the talent training target, curriculu $\mathrm{m}$ development, teacher training, top ic of research and development, training base construction. It actively explores and practises training applied talent in higher vocational education, and the model is innovative. Practice shows that college- enterprise cooperation based on "post-oriented, for ming college-enterprise win-win situation in cooperation in running colleges, cooperative education, cooperative employment, cooperative development.
\end{abstract}

\section{Construct training applied talents model of college-enterprise cooperation: post-oriented, integrating theory with practice}

\section{1 training applied talents model}

Applied electronic technology $\mathrm{m}$ ajor of the city vocational co llege of Jiangsu follows the guiding principle for running a college about "serve Jiangsu, serve electronic information industry, radiate changjiang delta", activ ely carries out cooperation between higher vocation college and enterprise; Through extensive research and demons tration, it made clear the direction of $\mathrm{m}$ ajor development and target orientation; On this basis, it $\mathrm{f}$ ormulated the major construction plan and major construction programm e; According to th e industrial structure adjustm ent and product upgrade to bring the change of applied talent dem and, it timely revising the a pplied talent training plan.

Based on the above, it put forward "t raining applied talents model of college- enterprise cooperation: post-oriented, integrating theory with practice" which has the characteristics of the city vocational college of Jiangsu

1) Post-oriented [1]

The so-called "post-oriented", nam ely, in or der to determine occupation post dem and, study organization of leading major teaching contents; In order to realize major training objectives, make sure implement of leading major teaching content; To use assessment standard of occupation post completes performance evaluation of leading major teaching content.

2 ) Integrating theory with practice

"integrating theory with practice ", namely, a teaching m ode of the integration of theory and practice, is to com bine theory course with practice course to carry ou t teaching. It not only make communication and contact of theory and practice, but also stim ulate students' learning interest and passion [2].

This teaching model emphasized to give full play to the leading role of teachers. By setting the teaching task and teaching target, make teachers teaching while students learning, doing, thereby to build quality and techn ical ability training fram ework, to rich classroom teaching and practice teaching, to improve teaching quality. In the whole teachin g process, theory and practice cou rses are alternate. Its purpose is to highlight cultivati on of the practical ability and professional skills of students, and fully $\mathrm{m}$ obilize and stimulate students interest in le arning, thus improve teaching efficiency and effect. 


\subsection{The relationship between post-oriented and integrating theory with practice}

"Post-oriented" reflects the post target of "servi ce purposes, em ployment guidance, ability training"; "Integrating theory with practice" em bodies the teaching mode of theory and practice integrating into one.

\section{The implementation process of training applied talents of college-enterprise cooperation on "post-oriented, integrating theory with practice"}

2.1 The content of training applied talents of college-enterprise cooperation based on "post-oriented, integrating theory with practice"

Through continuous exploration and ceaseless practice during several years, the city vocational college of Jiangsu enriches the contents of $t$ raining applied talents of college-enterprise cooperation based on "post-oriented, integrating theory with practice" in applied elec tronic technology major. These mainly includes [4]: targets of training applied talents drafted by college-enterprise cooperation, curriculums of developed b y college-enterprise cooperation, teachers traine $\mathrm{d}$ by college-enterprise cooperation, teaching and teaching reform conducted $\mathrm{b}$ y college-enterprise cooperation, topics researched and developed by colle ge-enterprise cooperation, practical training bases constructed b y college-enterprise cooperation etc.

2.2 The implementation process of training applied talents of college-enterprise cooperation on "post-oriented, integrating theory with practice"

\section{1) Targets of training applied talents drafted by college-enterprise cooperation}

In order to meet needs of training applied talents in enterprise, according to two training orientations of " LED technology " and " solar energy technology " in applied electronic technology major, we and som e relevant enterprises join tly formulate personnel tr aining target based on post-oriented.

One is we go to related enterprises to investigate the requirement of training applied talents. We investigated some enterprises and industrie s like Nanjing Lopu limited by share Ltd, Suzhou Siemens electrical company limited etc. Show that they need more than 2000 graduates of applied electronic technology major within the next three years. Main posts have production assem bly, drawing, testing, debugging, maintenance, production management and quality management.

Another is the related enterprises com e our college to discuss and establish jointly targets of training applied talents. We invited 17 enterprises of Nanjing Lopu lim ited by share Ltd, Suzhou Siemens electrical company lim ited etc. to co me our college to research and discus schem e of training applied talents and major construction, in order to further understa nd current situation of talent needs in enterprises. W e focus on two t raining orientations of "LED technology "and" solar energy technology" in applied electr onic technology major, and developed their targets of $t$ raining applied talents.

2) Curriculums of developed by college-enterprise cooperation

According to two training orientations of "LED technology" and "solar energy technology" in applied electronic technology $\mathrm{m}$ ajor, and linking analysis of post ta sks, we introduced som e required factors on knowledge, skills, quality and so on in major courses, jointly developed major courses with enterprise cooperation.

The course "electronic product drawing" has become the provincial excellent course by jointly developed with Shenzhen em door electronic te chnology company limited. In addition, the course "LED display control system" by jointly developed with Nanjing Lopu limited by share Ltd, and the course "technology of solar photovo ltaic application" by jointly developed with Nanjing kangni technology industry company Limited, Nanjing solar energy research institute company Limited have become the colleg e excellent courses. Th ese courses fully em bodies the combination with theory and practice.

3) Teachers trained by college-enterprise cooperation

The teacher team is the m ost important resource in colleges. It reflects the professional core competitive ability[3].

In recent years, my college increases investm ent to strength en teacher team construction in 
college-enterprise cooperation. In addition to intensify the intr oduction of talent $s$ to attract outstanding talents at ho me and abroad, we strengthen young backbone teachers training and to select teachers learning in enterprises.

First, the college selects youth teachers to cooperative enterprise to learn full-time.

Second, by using of lead studen ts to cooperative enterprise $s$ to be underway internship opportunities or cold vacation and summ er vacation, the college selects $m$ ajor teachers to th ese enterprises to practice.

Third, the college em ploy enterprise backbone technical personnel as a part-tim e teacher to enrich the team of major teachers.

4) Teaching and teaching reform conducted by college-enterprise cooperation

In order to improve the teachers teaching ab ility, we carry out the teaching ref orm with enterprises.

We select real products or projects as the carri er for major core courses and practice courses. In the teaching process, we strengthen the skills training. In the teaching method, we put into effect "integrating theory with practice".

So far, all the $m$ ajor core courses and practi ce courses are carried out the teaching $m$ ethod of "integration of theory and practice teaching". It plays an important role in reform of training applied talent.

5) Topics researched and developed by college-enterprise cooperation

In recent years, the teachers of applied electronic technology major cooperate with enterprises all the time. They hosted and participated in 16 longitudinal and transverse topics, and obtained two new practical type patents of invention.

6) Practical training bases constructed by college-enterprise cooperation

We cooperated with enterprises to build th e practical training ba se indoors-provincial demonstrative base "electronics and computer application training center" [5].

The base construction area is 2079 square meters, total equipment sets numbers are 1127, total value 11130000 yuan ( RMB), in which value 3510000 yuan equipment is donated by enterprises. The training base meets the needs of the normal teaching, in addition, Spare time opens to the students.

We cooperated with 17 enterprise s to build the stable practical training base outside. Our all students carry out practicing in these enterprises.

\section{Practice effect}

Through exploration and practice of several years, obtained certain result.

\subsection{Students and tutors competition awards}

In various competitions above the $\mathrm{p}$ rovincial level, the students wined nine awards. Among them, three students received the first prize; th e tutors wined five awards. Am ong them, three tutors received the first prize.

3.2 The students' employment quality

Initial employment rate of the graduates is over $98 \%$, the employment quality is overall better.

3.3 satisfaction of enterprises

The survey data shows that th e employing units were overall satisfactory for our graduates, and think that they can be competent at present post.

In graduates' ability, the em ploying units' $d$ egree of satisfaction was respec tively team cooperation consciousness, $67 \%$; professional knowledge, $61 \%$.

\section{Conclusion}

Practice shows that the college-enterprise cooperation model of "post-oriented, integrating theory with practice", effectively improve students operating skills and practical ability, so that our teachers and technical personnel of enterprises realize the information exchange, resource sharing to 
enhance the teachers' teaching level and teaching quality, to form win-win situ ation of college-enterprise cooperation in cooperative education, cooperative employment, cooperative development.

\section{Acknowledgments}

This research was supported by K ey Planning Topic Of Higher Education Science Research Of Jiangsu Province In The "12th Five-Year Plan"(Grant number KT2011081)

\section{Reference}

[1] Zhou Li. "Post-oriented" talent training model [EB/OL]. http://www. dxx.wxcu. edu.cn/ch15/ ShowInfo.asp? InfoID=269,2011.5.24

[2] Anonymous. Exploration on the teaching mode of integration of theory and Practice[EB/OL]. ttp://www.cdlqjy.com/zjw/zjky/201103/20110330092037_21822. html, 2011.3.30

[3] anonymous. Reflection on how to develop "double type" teachers under college-enterprise cooperation [EB/OL]. http://www.blog.fhedu.net.cn/user1/

fhhcz/2008626175958.html,2008.6.22

[4] The city vocational college of Jiangsu. An alysis report of a pplied electronic technology major[Z]. Nanjing: The city vocational college of Jiangsu. 2011

[5] Chen Wei, Fan $J$ un. Research on building tr aining center of $\mathrm{m}$ echanical and electronic integration major[J]. Research and exploration in laboratory, 2010 (4): 190-193

[6] Chen Wei, Fan Jun. Research of curriculum setting and teaching reform with the orientation of employment -- case study of $\mathrm{m}$ echanical and e lectronic integration $\mathrm{m}$ ajor of the $\mathrm{c}$ ity vocational college of Jiangsu [J]. Liaoning Higher Vocational Technical Institute journal, 2009 ( 11): 44-146

[7] Mycos. Annual report 2010 society demand and developing quality" ( 2011-05)

[EB/OL].http://cai.jstvu.edu.cn/czyp/showimagenews.aspx? Imgid=167, 2010.12.26 